\title{
Distribution of Igneous Rocks in Medina and Uvalde Counties, Texas, as Inferred from Aeromagnetic Data
}

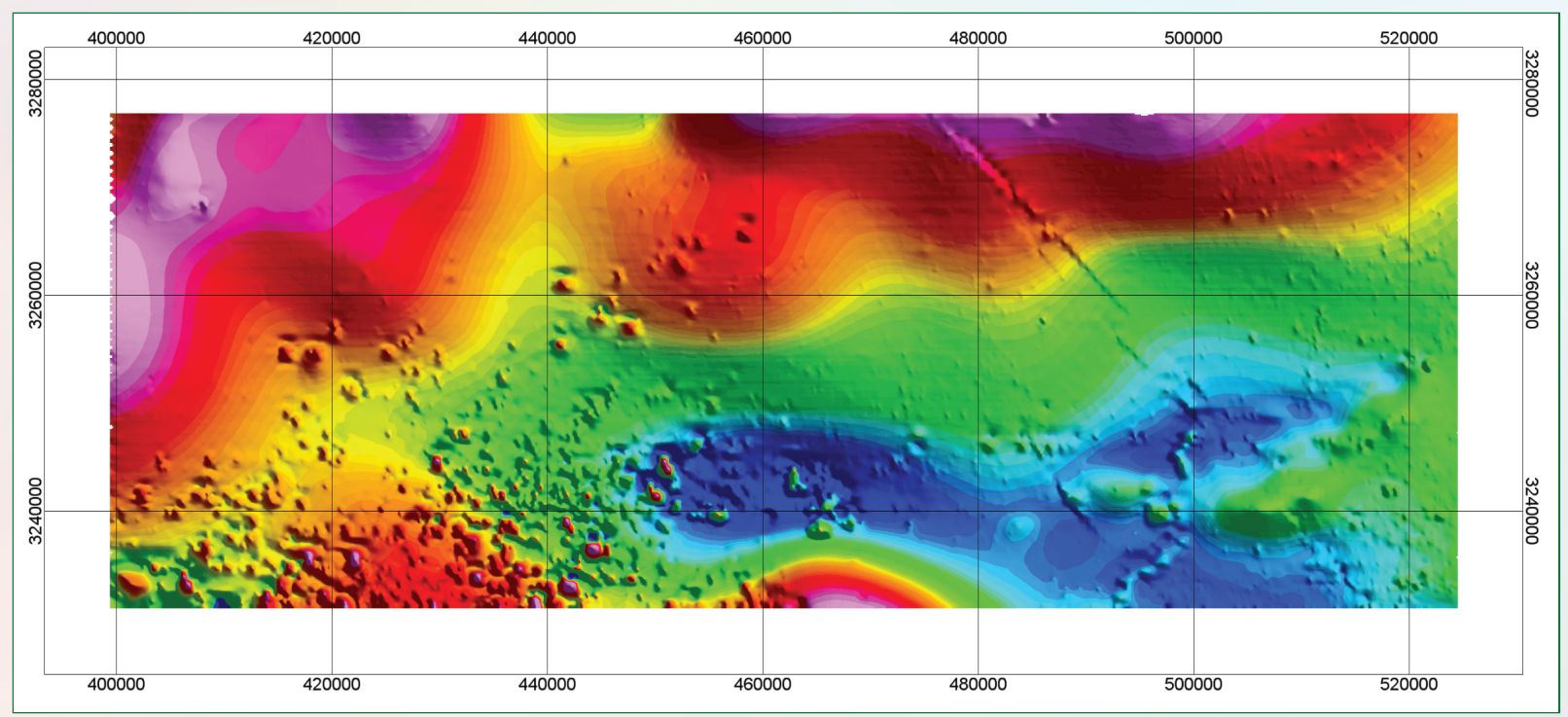

Scientific Investigations Report 2007-5191 



\section{Distribution of Igneous Rocks in Medina and Uvalde Counties, Texas, as Inferred from Aeromagnetic Data}

By David V. Smith, Robert R. McDougal, Bruce D. Smith, and Charles D. Blome

Scientific Investigations Report 2007-5191 


\section{U.S. Department of the Interior DIRK KEMPTHORNE, Secretary}

\section{U.S. Geological Survey \\ Mark D. Myers, Director}

\section{U.S. Geological Survey, Reston, Virginia: 2008}

For product and ordering information:

World Wide Web: http://www.usgs.gov/pubprod

Telephone: 1-888-ASK-USGS

For more information on the USGS--the Federal source for science about the Earth, its natural and living resources, natural hazards, and the environment:

World Wide Web: http://www.usgs.gov

Telephone: 1-888-ASK-USGS

Any use of trade, product, or firm names is for descriptive purposes only and does not imply endorsement by the U.S. Government.

Although this report is in the public domain, permission must be secured from the individual copyright owners to reproduce any copyrighted materials contained within this report.

Suggested citation:

Smith, D.V., McDougal, R.R., Smith, B.D., and Blome, C.D., 2008, Distribution of igneous rocks in Medina and Uvalde

Counties, Texas, as inferred from aeromagnetic data: U.S. Geological Survey Scientific Investigations Report 2007-5191,

12 p., one plate, scale 1:250,000. 


\section{Contents}

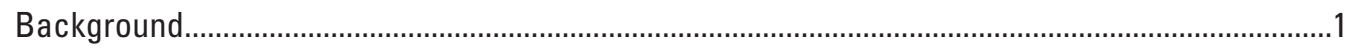

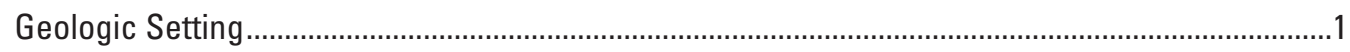

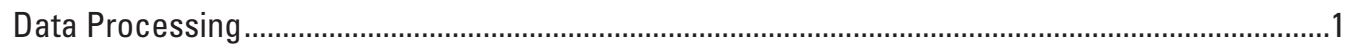

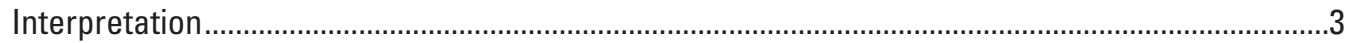

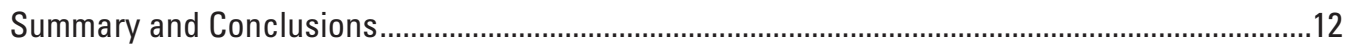

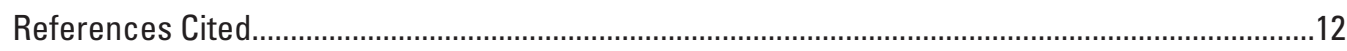

Appendix. Georeferenced Igneous Rock Outlines in ESRI File Formats ........................................12

\section{Plate}

1. Interpreted igneous intrusives from airborne magnetic data, Medina and Uvalde Counties, Texas

\section{Figures}

1-10. Maps showing:

1. Location of the study area in south-central Texas..................................................

2. High-resolution aeromagnetic survey flown in 2001, showing total magnetic field ......................................................................................................

3. Total magnetic intensity reduced-to-pole data …………..........................................

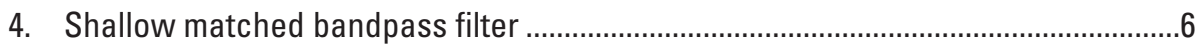

5. Deep matched bandpass filter ...........................................................................

6. Very deep matched bandpass filter ......................................................................

7. An isolated magnetic anomaly interpreted as a volcanic pipe..................................9

8. Horizontal gradient image annotated with different signal sources.........................10

9. Horizontal gradient image overlain with filled contours ..........................................11

10. Filled, validated magnetic anomaly contours ...........................................................11 



\title{
Distribution of Igneous Rocks in Medina and Uvalde Counties, Texas, as Inferred from Aeromagnetic Data
}

\author{
By David V. Smith, Robert R. McDougal, Bruce D. Smith, and Charles D. Blome
}

\section{Background}

A high-resolution aeromagnetic survey was flown in 2001 over Medina and Uvalde Counties, Texas, as part of a multidisciplinary investigation of the geohydrologic framework of the Edwards aquifer in south-central Texas (Smith and others, 2002; this report, fig. 1). The objective of the survey, which was funded jointly by the USGS and the San Antonio Water System, was to assist in mapping structural features that influence aquifer recharge and ground-water flow. Igneous rocks were noted in the earliest surveys of this area, particularly in the vicinity of Uvalde, Texas (Lonsdale, 1927; Sayre, 1936). In the literature, this region is referred to as the Uvalde igneous field, comprising the southwest half of the more extensive Balcones igneous province (Ewing and Caran, 1982). This aeromagnetic survey revealed hundreds of magnetic anomalies associated with igneous rocks that had previously been unmapped. As a follow-up to release of the data in 2002, this report presents an interpretation of the outcrops and subcrops of igneous rocks, based upon procedures of matched-filtering and potential field modeling.

\section{Geologic Setting}

The sedimentary formations of this region consist of limestones, chalks, sandstones, shales, and clays. Thick deposits of unconsolidated sands and gravels occur in major flood plains. Episodes of Late Cretaceous volcanic activity resulted in the emplacement of numerous and widely scattered igneous bodies. The Uvalde igneous field consists of fine- to coarse-grained ultramafic and hypabyssal rocks that occur as dikes, plugs, and shallow intrusions. Recent radiogenic dating identifies two distinct phases of magmatic activity. The first phase of intrusions was emplaced approximately 82-80 Ma, and the younger phase, consisting of phonolites, was emplaced approximately 74-72 Ma (Miggins and others, 2004).

Although some lie exposed at the surface, most are concealed beneath Tertiary sedimentary deposits and Quaternary alluvium. Igneous rocks typically have a much higher magnetic susceptibility than sedimentary rocks (Clark, 1966). In the same outcrop, values can vary by several orders of magnitude (Blakely, 1996), and therefore significant statistical overlap exists among different rock types. Among sedimentary rocks, carbonates have low susceptibilities compared to sandstones, siltstones, and mudstones. Because pure calcium carbonate $\left(\mathrm{CaCO}_{3}\right)$ has a small negative susceptibility (CRC, 1990), any positive bulk susceptibility arises from inclusions of ferrimagnetic minerals associated with the deposit. Field measurements of bulk magnetic susceptibility were made of fresh hand samples using a GeoInstruments GMS-2 portable magnetic susceptibility meter. Limestone specimens exhibited mean values of $0-2 \times 10^{-5}$ SI units; volcanic specimens ranged from $1,100-3,600 \times 10^{-5}$ SI units. The highest values were observed in unaltered rock samples from the Vulcan Quarry in Knippa, Texas. Because the limestone country rock contains negligible magnetite and other ferrimagnetic minerals, it contributes little to the measured magnetic anomalies, thus making it effectively invisible.

\section{Data Processing}

The contractor that flew the survey, Spectra Geophysics of Canada (now Fugro Services), acquired the raw data and applied routine corrections and leveling procedures. A description of the survey, along with data files, is available for download (see Smith and others, 2002). For this investigation, the data were further processed to enhance the magnetic signatures of shallow sources. After despiking with a nonlinear filter to remove transients above $1.0 \mathrm{nT}$, the data were gridded using a standard minimum curvature algorithm with a cell dimension of $80 \mathrm{~m}$, which is one-fifth of the survey flightline spacing. The map of the total magnetic field, shown in figure 2 , reveals numerous shallow magnetic bodies against a background of broader, deeper source rocks. Shallow igneous rocks cause very localized (short spatial wavelength) magnetic anomalies. Deeper intrusive and crystalline basement rocks cause broad regional (long wavelength) anomalies. Cultural features, such as pipelines and highways, are also discernible because of their distinctly linear appearance.

The Earth's main field is inclined about $58^{\circ}$ over the survey area. This causes most magnetic anomalies to appear dipolar. That is, a strong positive peak is associated with a weaker negative peak to the north, appearing as a crescent-shaped depression. The location of the positive peak, rather than being directly above the magnetic source, is shifted to the south of the causative body. A mathematical procedure, 

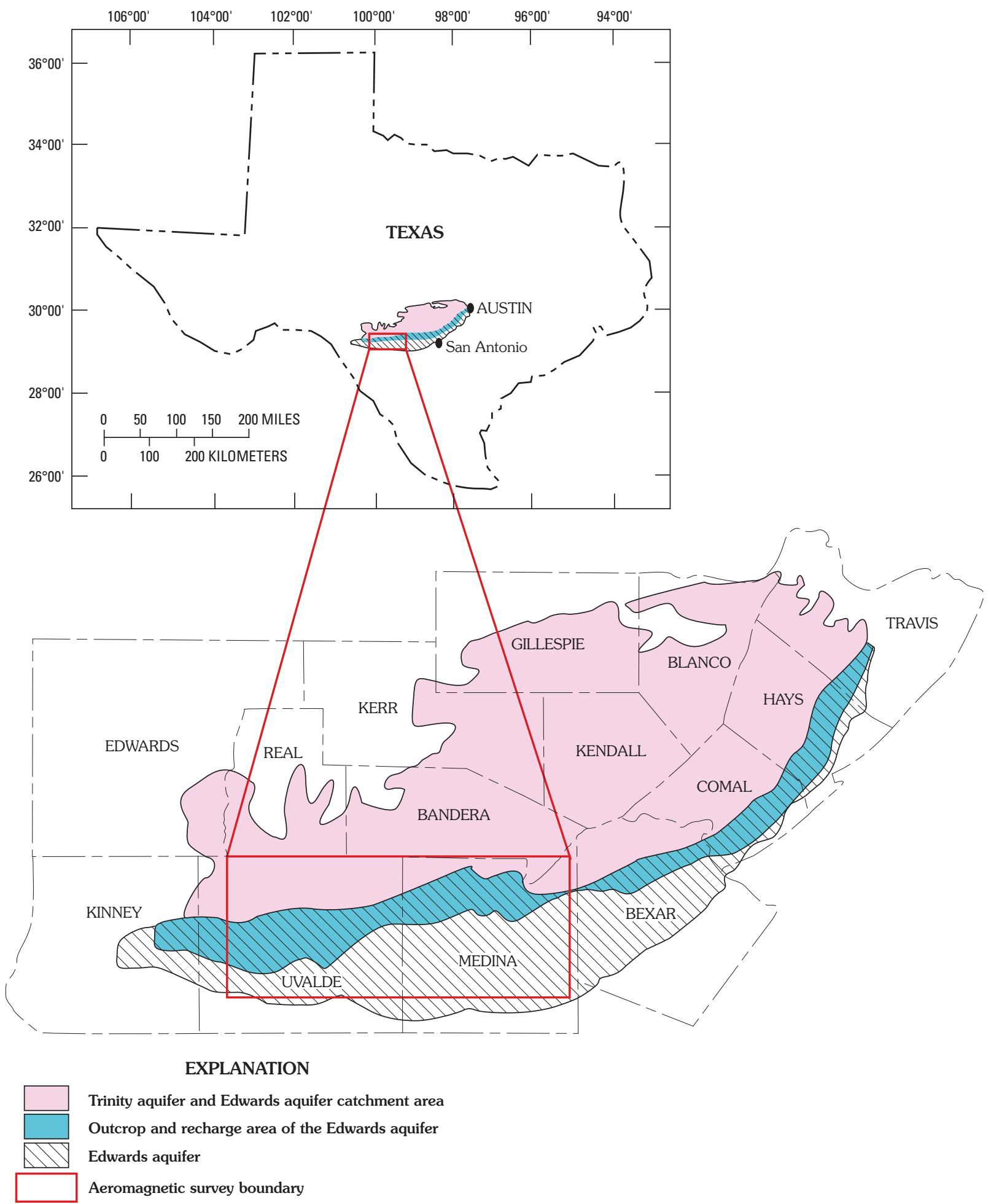

Trinity aquifer and Edwards aquifer catchment area

Outcrop and recharge area of the Edwards aquifer

Edwards aquifer

Aeromagnetic survey boundary

Figure 1. Index map showing the high-resolution aeromagnetic (HRAM) study area. From Barker and Ardis (1996). 
called reduction to the pole, makes it possible to represent the data as though the Earth's field is perpendicular to the area, as at the North Pole (Blakely, 1996). An assumption is made that the direction of induced magnetization is in the direction of the main magnetic field. Consequently, this technique does not account for the effects of remanent magnetization. Applying this transformation shifts most of the anomalies over their magnetic sources, as evident in figure 3 . This has the effect of suppressing the large magnetic low in the central part of the survey area. This prominent low was due in large part to the strong magnetic source at the center of the southern border. The edge of the broad magnetic high in the northern part of the survey area is due to the decreasing depth of the basement. The broad magnetic low in the central part of the east half of the survey area corresponds to thick deposits of low-susceptibility sedimentary deposits.

Magnetic anomalies can be differentiated according to depth using the technique of matched bandpass filtering, in which the spectra of equivalent magnetic sources at specified depths are matched to the spectra of observed anomalies. The software used for this is contained in the suite of potential field data processing utilities developed and maintained by the USGS (Phillips, 1997). Initially, the user interactively selects spatial frequency bands against a graphical display of the data set's radial power spectrum. The initial picks are refined automatically by an iterative curve-matching process. The aeromagnetic data in the present study are readily decomposed into three equivalent layers, corresponding to shallow, deep, and very deep sources, respectively. The three layers are gridded and displayed using the same parameters as for the total magnetic field maps.

Figure 4 shows relatively shallow equivalent sources, nominally $260 \mathrm{~m}$ below the surface. Swarms of small pipes and plugs are scattered throughout southern Uvalde County, with numerous small, isolated anomalies to the north and in Medina County to the east. Note cultural noise scattered throughout, especially the long linear features to the east due to pipelines.

Figure 5 shows relatively deep equivalent sources, approximately 5,500 m deep. Numerous sources continue to moderate depth, especially in southern Uvalde County. The prominent source at the center of the southern boundary may be due to an extensive sill complex. The two large anomalies to the southeast may be due to horst blocks.

Figure 6 shows very deep equivalent sources, approximately 15,400 $\mathrm{m}$ deep. The magnetic basement rocks appear to the north in the vicinity of the Balcones fault zone. Thicker sedimentary layers occur south of this major fault zone. Two deep magnetic sources occur at the southern boundary, and may represent the stock for many of the observed intrusives.

\section{Interpretation}

The shallow matched bandpass filter layer (fig. 4) contains the information needed to map the distribution of near-surface igneous rocks. However, effects of noise and culture have to be removed. At the flying altitude of $167 \mathrm{~m}$, a geologically significant magnetic source would have to affect at least three adjacent flightlines, which are spaced $400 \mathrm{~m}$ apart. A sudden spike affecting just one flightline, for example, would indicate a probable data acquisition error. The data were validated using a number of techniques and checked against corroborating sources. Anthropogenic sources were identified using in-flight videos of the land surface beneath the airplane, high-altitude aerial photography, high-resolution (1 m per pixel) satellite images, geographic information system (GIS) layers from the Texas Natural Resources Information System (TNRIS) (www.tnris.state.tx.us/); the Texas General Land Office Geographic Information Systems Data (www.glo.state.tx.us/gisdata/gisdata.html); the U.S. Fish and Wildlife Service (www.fws.gov/data/statdata/txdata.html); and recent published maps (all URLs accessible as of November 30, 2007). Finally, gradient filters were used to enhance high-frequency noise-like signals while suppressing lower frequency geologic signals.

Because the magnetic anomalies measured at the flying altitude are much larger in extent than the magnetic source at the surface, several assumptions have to be made in estimating the areal extent of the sources. One powerful technique is magnetic modeling of an equivalent source body. The commercial software package QuickMag Pro, a product of Encom Technology, Ltd., was used to process individual anomalies extracted from the entire data set. Descriptions of how the software works for this application can be found on the company's Web page (accessible at URL http://www.encom.com.au/, checked on November 30, 2007). This particular software package models sources as tabular prismatic bodies only, and works best with compact, well-defined anomalies. Compact bodies, such as volcanic pipes, plugs, and lava lakes associated with subaerial craters, can be represented by the models. The magnetic features of eroded tuff cones and associated pyroclastic flows, and larger scale structural features, such as unroofed laccoliths, are more disseminated. With these structures, the prismatic model approximation breaks down, as their more complex magnetic field patterns suffer from nonuniqueness of possible model solutions. Interpretations are further limited by the assumptions of a uniform magnetic susceptibility throughout the prismatic body, and of induced magnetization in the direction of the Earth's main magnetic field. Consequently, remanent magnetization and reverse magnetization effects are unaccounted for in these models. Indeed, reversely magnetized bodies are evident in the data. In spite of these limitations, the models are useful in establishing a magnetic field threshold that closely contours the horizontal extent of the igneous body. An example of a modeled anomaly from the survey data set is given in figure 7, which shows the best match as a near-vertical cylindrical pipe. Many discrete, isolated anomalies were modeled giving similar results. It can be seen that the cross-sectional area of the pipe is much smaller than the anomaly it causes. This broadening of the observed magnetic field anomaly due to body geometry and measurement distance must be accounted for when delineating igneous bodies. A simple and effective method uses the horizontal gradient of the total field to spatially constrict the anomalies. An edge of the body is then approximated by finding a gradient threshold that agrees with the interpretive model. 


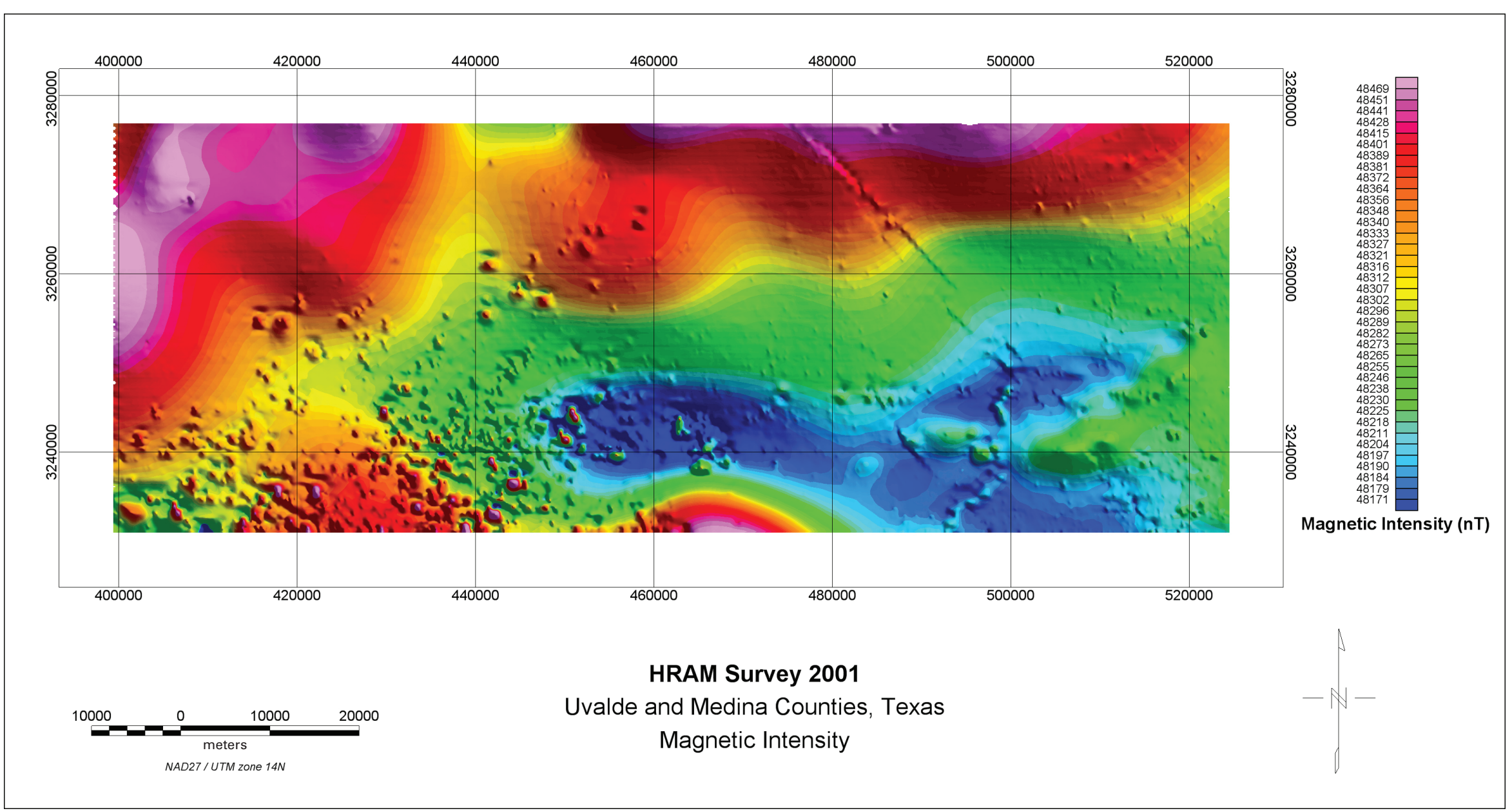

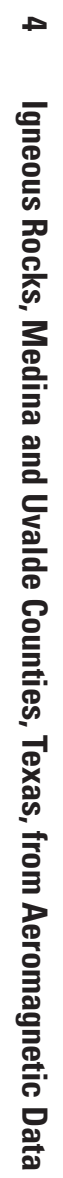

Figure 2. High-resolution aeromagnetic survey of Uvalde and Medina Counties, Texas, flown in 2001, showing total magnetic field. See figure 1 for geographic location. 


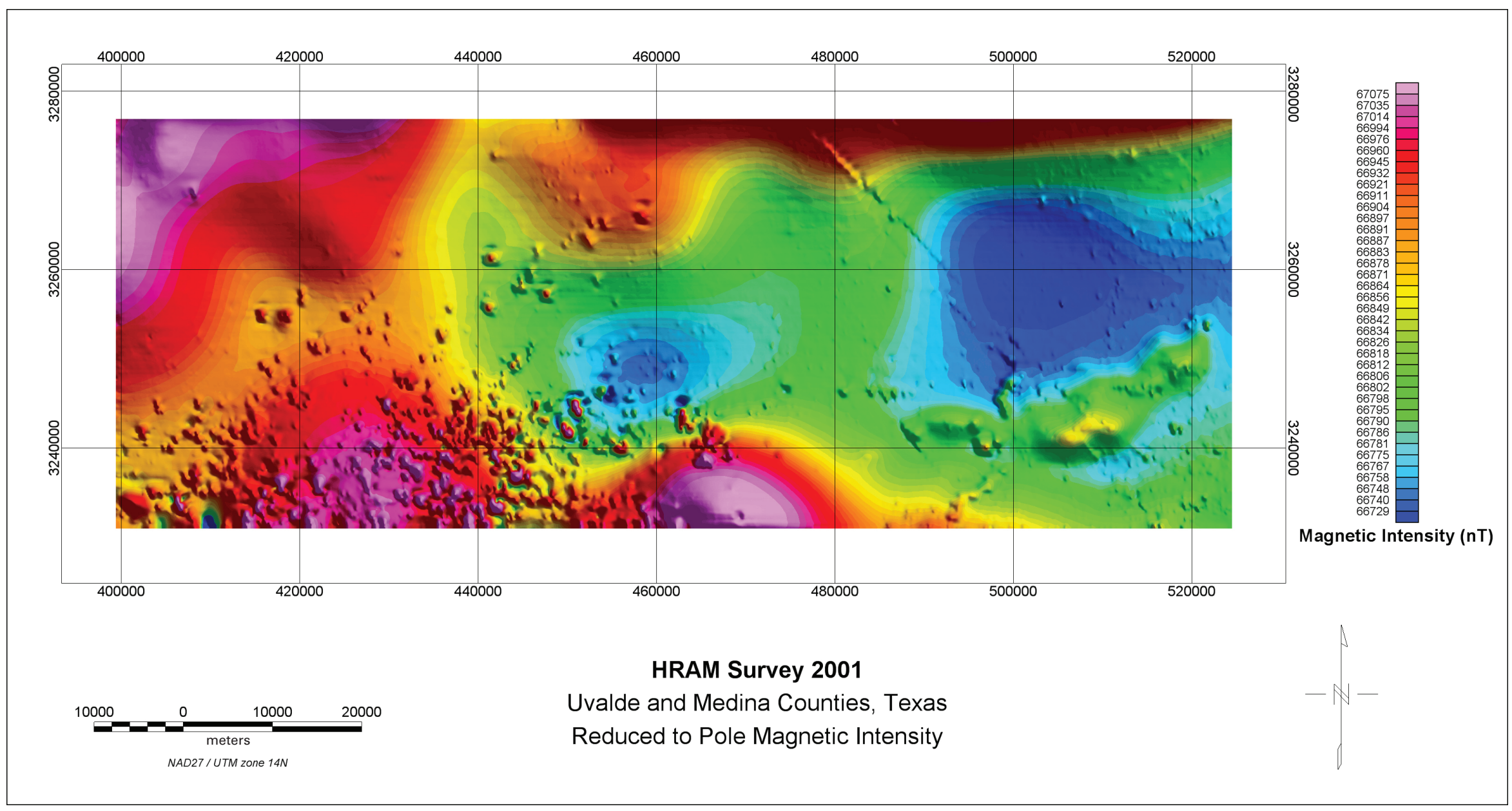

Figure 3. Total magnetic intensity reduced-to-pole data. The magnetic lows around most of the anomalies have been eliminated, especially the broad low in the central region, which was associated with the prominent magnetic high on the south edge of the survey area. The broad magnetic highs at the northern boundary correspond to shallower basement north of the Balcones fault zone. 


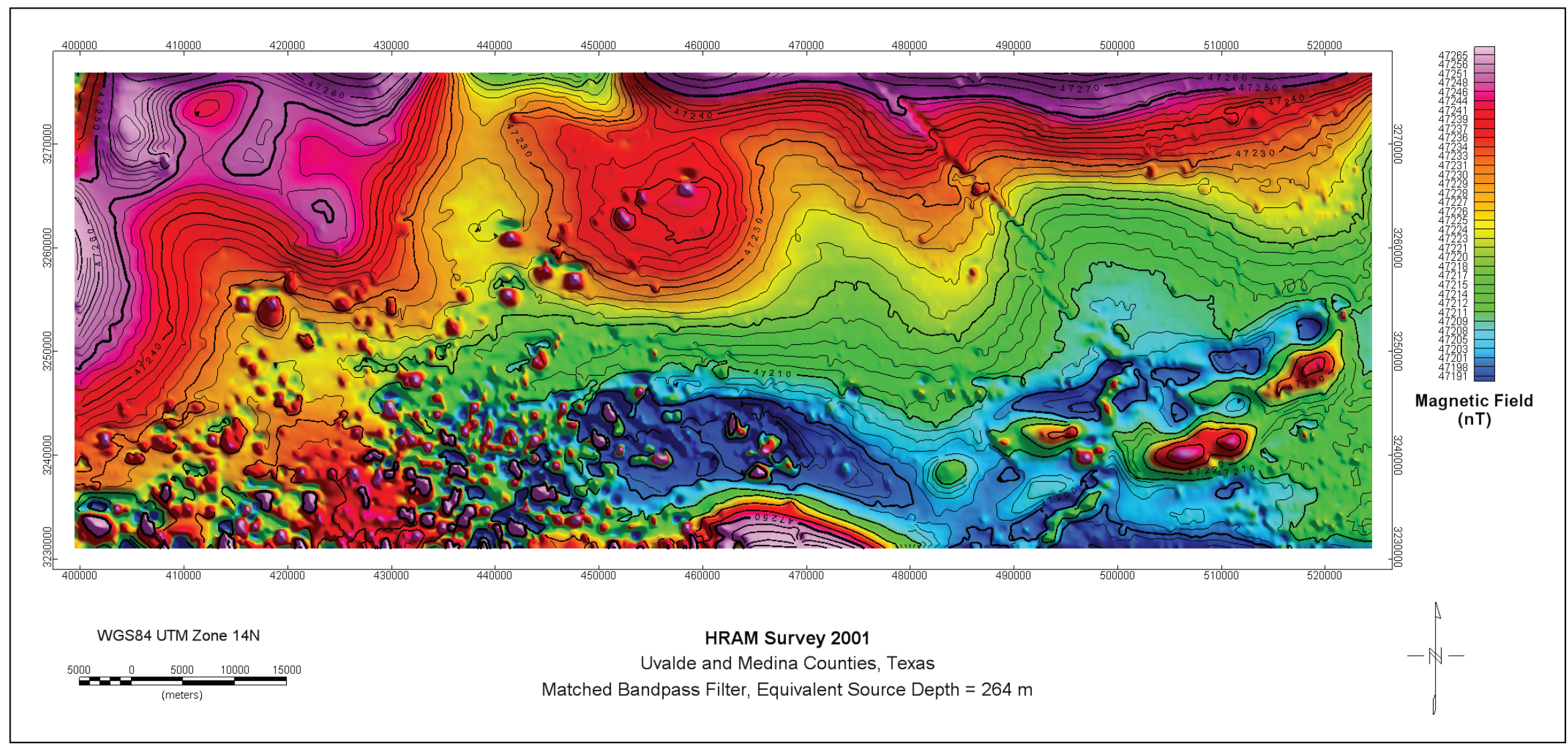

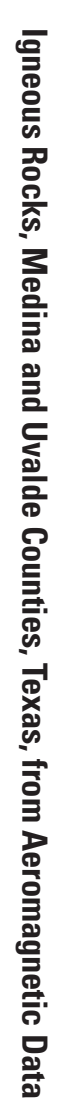

Figure 4. Shallow matched bandpass filter, 264-m-deep equivalent magnetic source layer. 


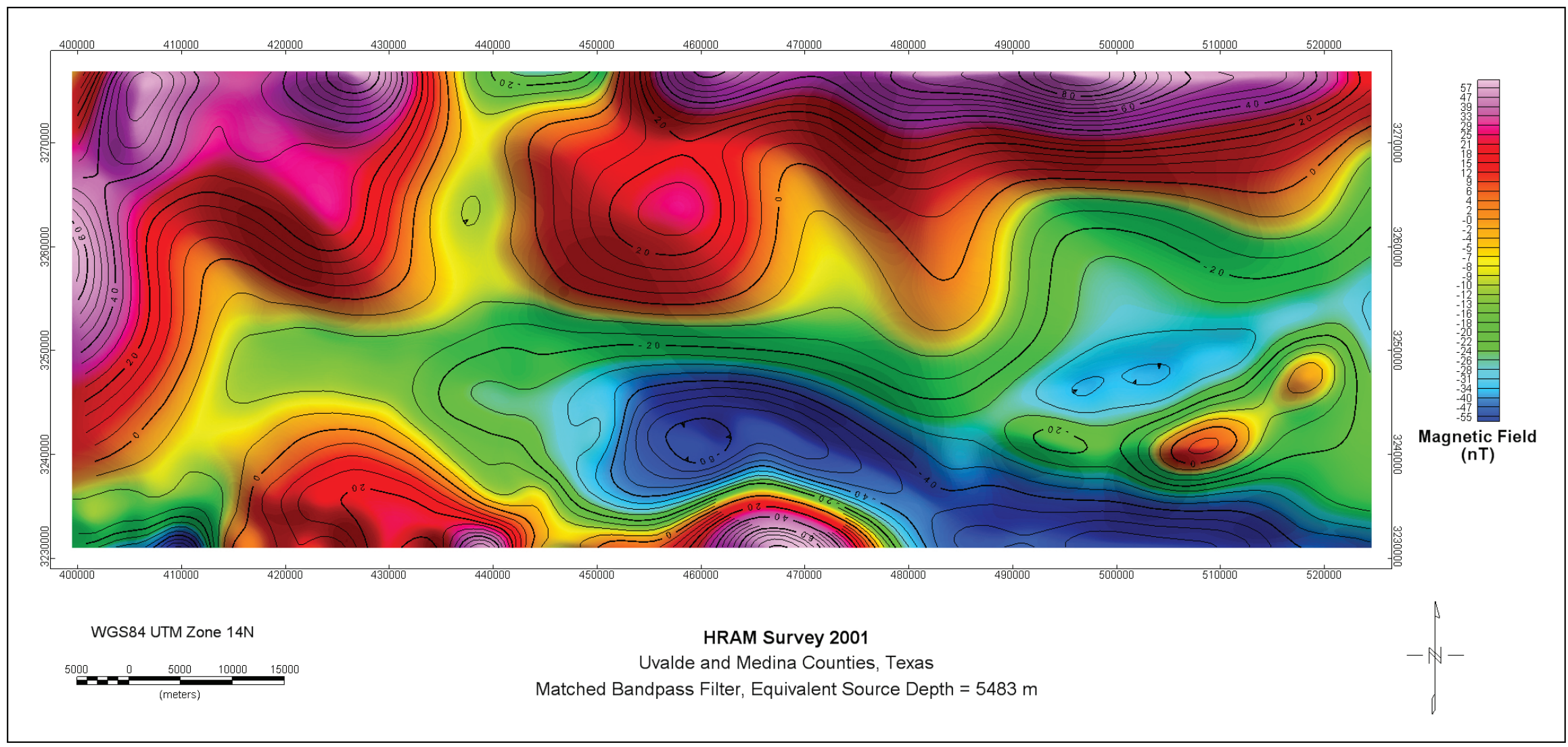

Figure 5. Deep matched bandpass filter, 5,483-m-deep equivalent magnetic source layer. 


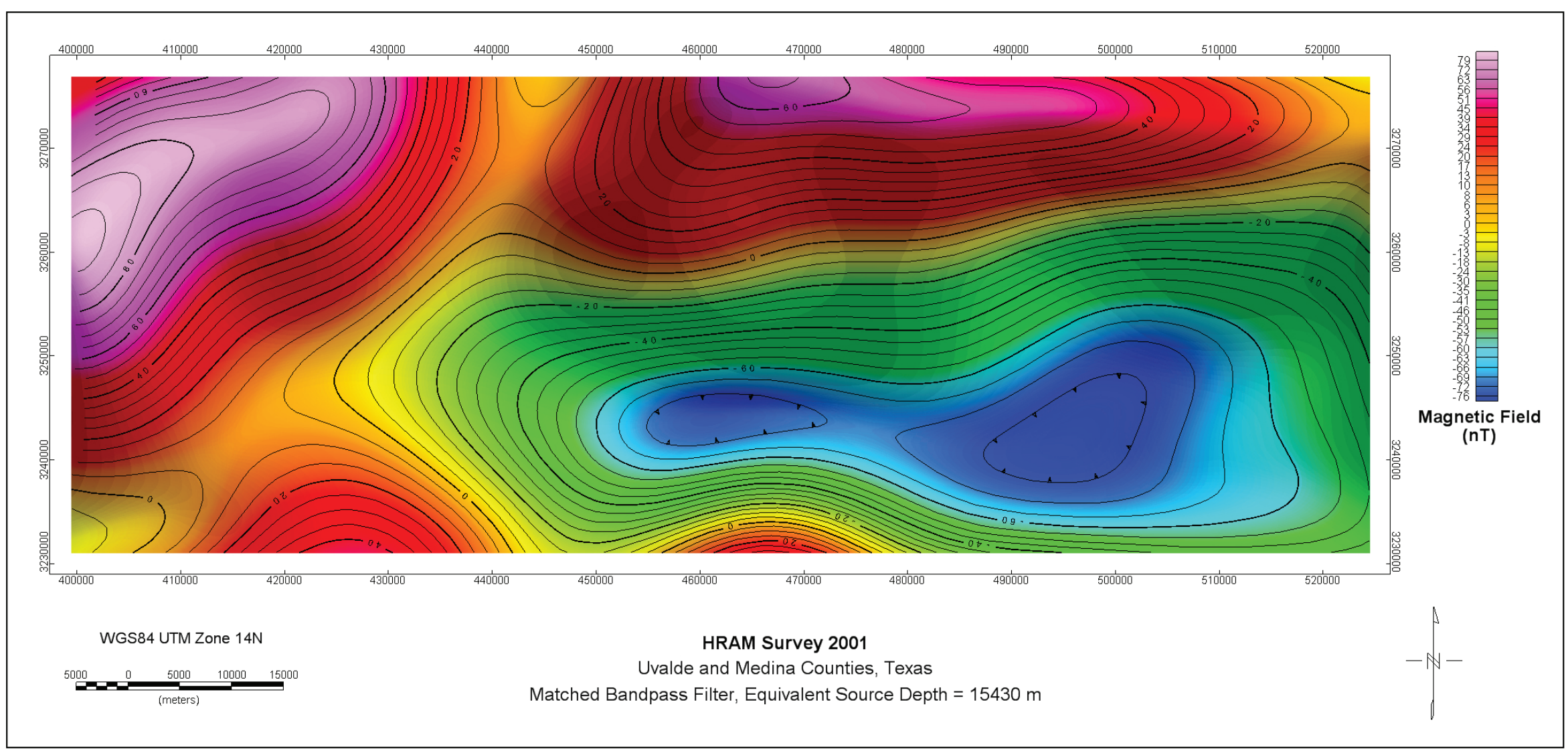

Figure 6. Very deep matched bandpass filter, 15,430-m-deep equivalent magnetic source layer. 


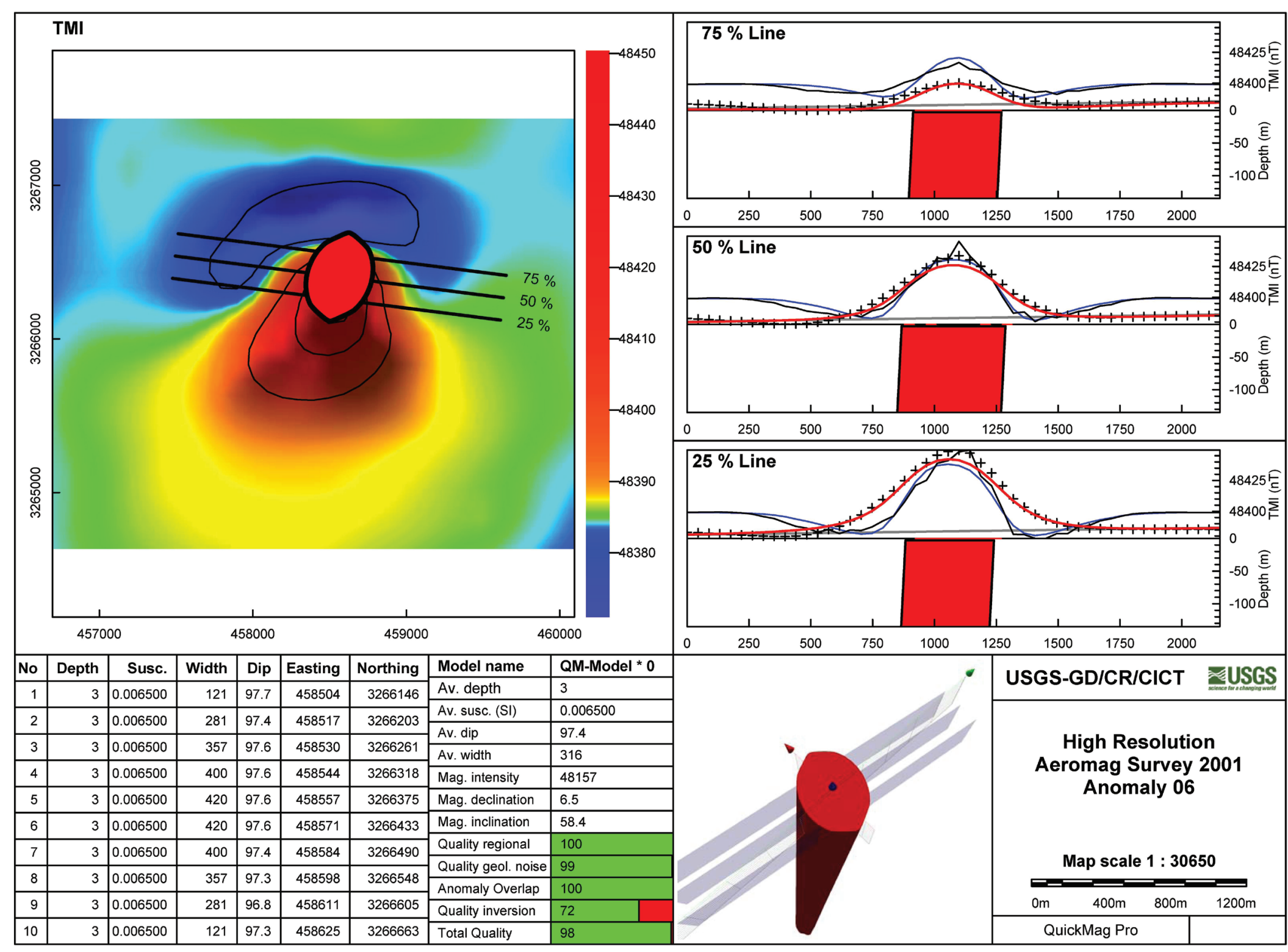

Figure 7. An isolated magnetic anomaly interpreted as a volcanic pipe. Due to the separation distance from the magnetic body to the magnetometer on the airplane, the anomaly appears much larger in size than the cross-sectional area of the modeled pipe. The prism model comprises 10 segments. The table under the map gives parameters for each segment, with distances in meters, susceptibility in SI units, and dip angle in degrees. The three charts in the upper right show the modeled prismatic body with graphs of actual (black lines and symbols) versus modeled (red and blue lines) data profiles. 
For thresholding purposes, a map of the total horizontal gradient was created, shown in figure 8, with several different types of features annotated. The horizontal gradient offers the advantage of sharpening localized magnetic anomalies against the more gradually varying background field, such as a regional gradient. In addition to compressing the spatial extent of the total magnetic field anomaly, isolated anomalies in the gradient image display a central dimple because the tangent plane at an anomaly's peak is horizontal. Therefore, the horizontal gradient is zero. As previously mentioned, nongeological signals are emphasized as well as geological signals. These include transient noise spikes on a single flightline, labeled "noise" in the figure; amplitude shifts caused by different flying elevations, labeled "leveling error"; clustered anomalies due to civil infrastructure, labeled "population center"; anomalies strung out along roads and highways, labeled "highway"; and unusually straight features due to cathodically protected buried pipelines, labeled "pipeline." Through trial and error, the level of $4 \mathrm{nT} / \mathrm{m}$ was found to delineate areas that closely agreed with the QuickMag models. The level is positive, in the sense that convex anomalies have a positive horizontal gradient, whereas concave anomalies have a negative horizontal gradient. Thus, by contouring the horizontal gradient data at the threshold level of $4 \mathrm{nT} / \mathrm{m}$, and eliminating the anomalies identified as noise, it is possible to outline areas containing shallow igneous bodies. An image of this outcome is given in figure 9, where the contours have been filled with red for enhanced visibility.

The final interpretive map was produced by creating two overlapping GIS layers. First, the contours identified as shallow igneous bodies (fig. 10) were digitized as polygons and attributed as to geographic location and area using the software package ERDAS Imagine version 8.6 (Leica Geosystems LLC; accessed at URL http://gi.leica-geosystems.com/LGISub1x20x0.aspx on August 21, 2006 (URL valid on November 30, 2007)). The GIS coverage was topologically "built" and saved as an ARC coverage (ARC interchange format) and shapefile. Next, the topographic base map was created by mosaicking two USGS 1:250,000-scale topographic maps of San Antonio and Del Rio, Texas (UTM zone 14, North American Datum 1927). The digital mosaic was georeferenced using 50 control points evenly distributed throughout the image and a second order polynomial warp method. Finally, the coverage of shallow igneous rocks was adjusted to a transparency of 50 percent and overlaid on the georeferenced digital base map (plate 1). An 11×17 inch document of this map is in Adobe PDF format and included as plate 1. The outlines of igneous rocks were output as a georeferenced SHP file, which is accessed in the Appendix to this report along with associated GIS files and metadata.

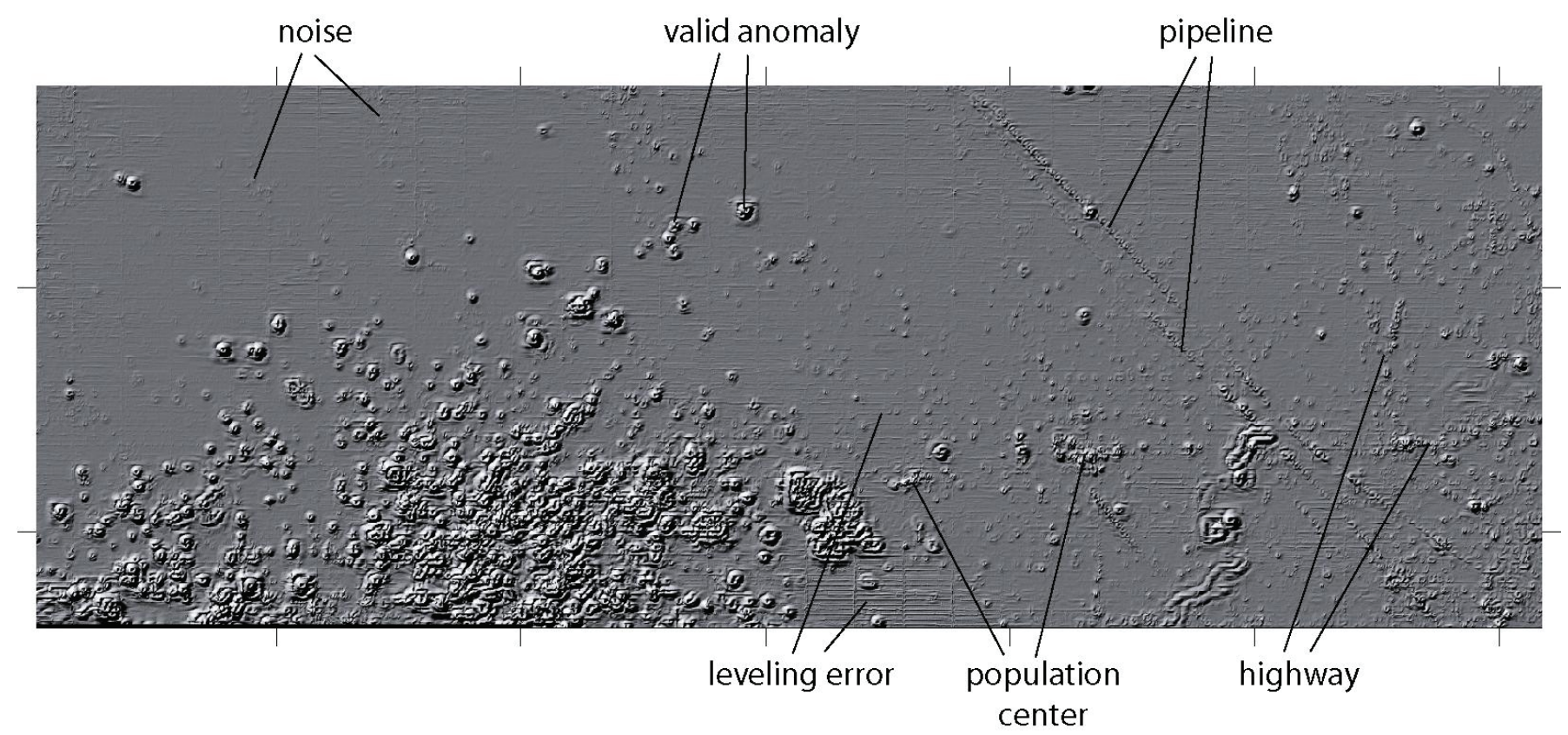

Figure 8. Horizontal gradient image annotated with different signal sources. Several steps were followed to validate those anomalies due solely to geologic sources. Same geographic area as aeromagnetic survey boundary in figure 1. 


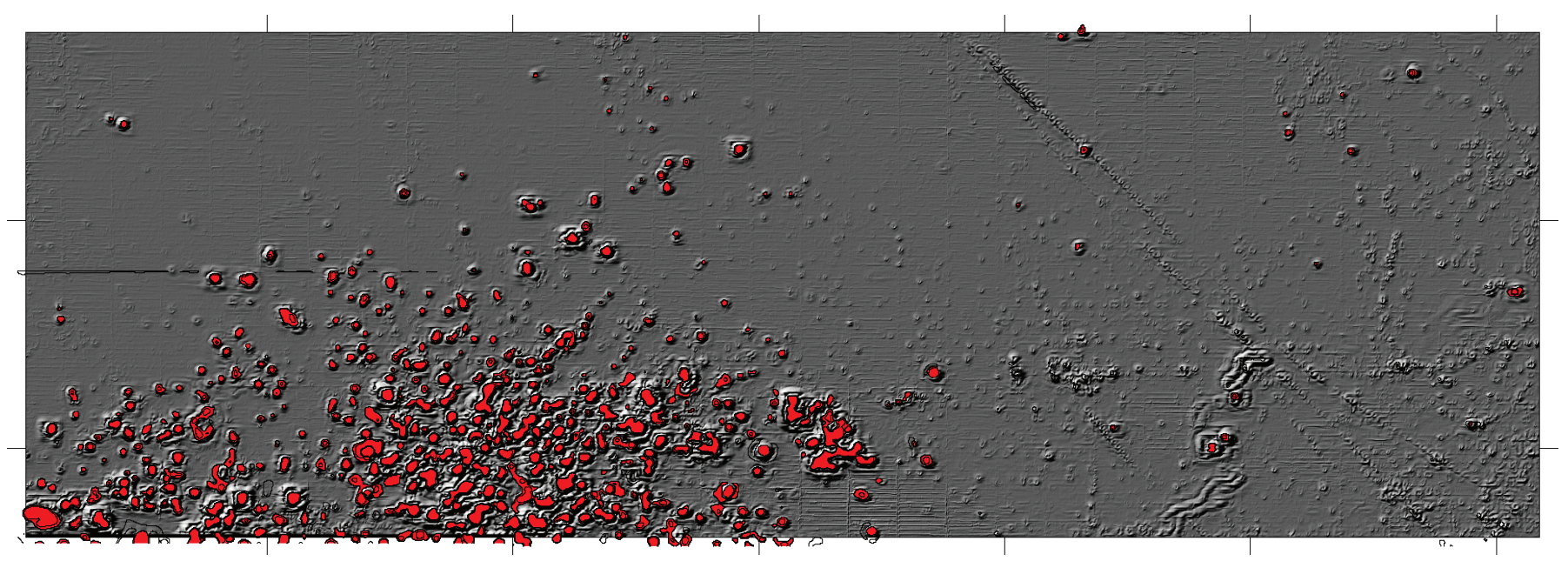

Figure 9. Horizontal gradient image overlain with filled contours. Igneous rocks are distinguished from other features that are interpreted as cultural noise or non-igneous structures.

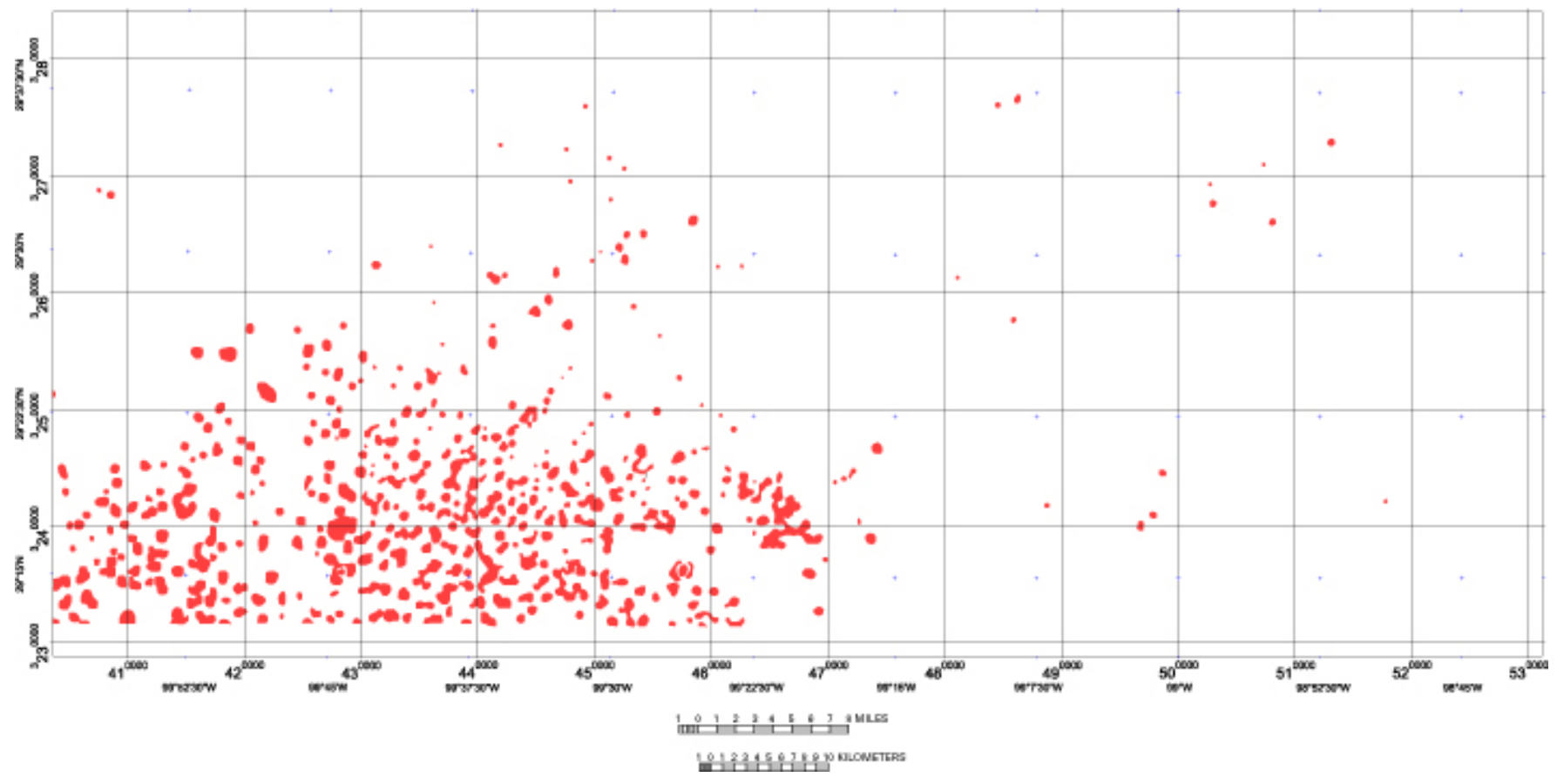

Figure 10. Filled, validated magnetic anomaly contours prepared as a vector graphics transparency layer. 


\section{Summary and Conclusions}

High-resolution aeromagnetic data, acquired in 2001, have been processed and interpreted to produce a map of the occurrence of shallow igneous rocks in Medina and Uvalde Counties, Texas. Necessary steps involved (1) potential field processing to separate magnetic sources according to depth of equivalent source layers; (2) magnetic modeling of discrete pipe-like anomalies to estimate their cross-sectional areas; (3) horizontal gradient filtering to enhance small-scale magnetic anomalies; (4) selection and application of a horizontal gradient threshold that approximates the lateral extent of magnetic bodies; (5) comparison of magnetic gradient images to existing maps and airborne images in order to discriminate between geologic sources and cultural noise; and (6) preparation of a transparency layer containing filled contours of validated anomalies. A final map was produced depicting the occurrence of igneous rocks in the survey area.

Because it was not possible to field check all the indicated locations to determine whether igneous rocks are exposed at the surface, it is possible that some are erroneous, despite best efforts to validate the aeromagnetic data. However, a comparison of this map to existing geologic maps of the survey area exhibits close agreement in the location of known igneous rock outcrops.

\section{References Cited}

Barker, R.A., and Ardis, A.F., 1996, Hydrogeological framework of the Edwards-Trinity aquifer system, west-central Texas: U.S. Geological Survey Professional Paper 1421-B, 61 p., 8 plates.

Blakely, R.J., 1996, Potential theory in gravity and magnetic applications: New York, Cambridge University Press, p. 90.
Clark, S.P., ed., 1966, Handbook of physical constants: Geological Society of America Memoir 97, p. 548.

Ewing, T.E., and Caran, S.C., 1982, Late Cretaceous volcanism in south and central Texas-Stratigraphic, structural and seismic models: Gulf Coast Association of Geological Societies Transactions, v. 32, p. 137-145.

Lonsdale, J.T., 1927, Igneous rocks of the Balcones fault region of Texas: University of Texas Bulletin 2744, 178 p.

Miggins, D.P., Blome, C.D., and Smith, D.V., 2004, Preliminary ${ }^{40} \mathrm{Ar} /{ }^{39} \mathrm{Ar}$ geochronology of igneous intrusions from Uvalde County, Texas-Defining a more precise eruption history for the southern Balcones Volcanic Province: U.S. Geological Survey Open-File Report 2004-1031, 31 p. (Available at URL http://pubs.usgs.gov/of/2004/1031/).

Phillips, J.D., 1997, Potential-field geophysical software for the PC, version 2.2: U.S. Geological Survey Open-File Report 97-725 (Available at URL http://pubs.usgs.gov/ of/1997/ofr-97-0725/pfofr.htm).

Sayre, A.N., 1936, Geology and groundwater resources of Uvalde and Medina Counties, Texas: U.S. Geological Survey Water-Supply Paper 678, 146 p.

Smith, D.V., Smith, B.D., and Hill, P.L., 2002, Aeromagnetic survey of Medina and Uvalde Counties, Texas: U.S. Geological Survey Open-File Report 02-0049 (Available at URL http://pubs.usgs.gov/of/2002/ofr-02-0049/).

Smith, D.V., and Pratt, D., 2003, Advanced processing and interpretation of the high resolution aeromagnetic survey over the central Edwards Aquifer, Texas [abs.]: Proceedings of the Society for the Application of Geophysics to Engineering and Environmental Problems, p. 374.

Weast, R.C., ed., 1990, Handbook of chemistry and physics: Boca Raton, Fla., CRC Press, Inc., 70th Edition, p. E-130.

\section{Appendix. Georeferenced Igneous Rock Outlines in ESRI File Formats}

$\begin{array}{ll}\text { File Name } & \text { Size } \\ \text { igneousOutlines.SHP } & 132 \mathrm{~KB} \\ \text { igneousOutlines.SHX } & 4 \mathrm{~KB} \\ \text { igneousOutlines.PRJ } & 1 \mathrm{~KB} \\ \text { igneousOutlines.DBF } & 25 \mathrm{~KB} \\ \text { igneousOutlines_meta.shp.xml } & 20 \mathrm{~KB}\end{array}$

NAD27 UTM Zone $14 \mathrm{~N}$ meters (390 polygons)

(No user-defined items)

Plate 1: Base Map in PDF Format

File Name

igneousMedinaUvaldeTopo.PDF
Size

$59780 \mathrm{~KB}$ 